\title{
Relationships between different types of fruit and vegetable consumption and serum concentrations of antioxidant vitamins
}

\author{
Luc Dauchet ${ }^{1}$, Sandrine Péneau ${ }^{2}$, Sandrine Bertrais ${ }^{2}$, Anne Claire Vergnaud ${ }^{2}$, Carla Estaquio ${ }^{2}$, \\ Emmanuelle Kesse-Guyot ${ }^{2}$, Sébastien Czernichow ${ }^{3}$, Alain Favier ${ }^{4}$, Henri Faure ${ }^{4}$, Pilar Galan ${ }^{2}$ \\ and Serge Hercberg ${ }^{3 *}$
}

${ }^{1}$ INSERM, U557, Bobigny, France; INRA, U1125, Bobigny, France; CNAM, EA3200, Bobigny, France; Univ Paris13, Bobigny, France; CRNH IdF, Unité de Recherche en Epidémiologie Nutritionnelle, Bobigny F-93017, France and Department of Epidemiology and Public Health, Rouen University Hospital, Rouen, France 74 rue Marcel Cachin, Bobigny Cedex 93017, France ${ }^{2}$ INSERM, U557, Bobigny, France; INRA, U1125, Bobigny, France; CNAM, EA3200, Bobigny, France; Univ Paris13, Bobigny, France; CRNH IdF, Unité de Recherche en Epidémiologie Nutritionnelle, Bobigny F-93017, France 74 rue Marcel Cachin, Bobigny Cedex 93017, France

${ }^{3}$ INSERM, U557, Bobigny, France; INRA, U1125, Bobigny, France; CNAM, EA3200, Bobigny, France; Univ Paris13, Bobigny, France; CRNH IdF, Unité de Recherche en Epidémiologie Nutritionnelle, Bobigny F-93017, France and Département interhospitalier de santé publique, Hôpital Avicenne, Bobigny, AP-HP, France 74 rue Marcel Cachin, Bobigny Cedex 93017, France ${ }^{4}$ Département de biologie intégrée Bâtiment B, CHU La Tronche, Grenoble, France bd Chantourne, La Tronche 38700, France

(Received 21 May 2007 - Revised 20 November 2007 - Accepted 6 December 2007 - First published online 18 February 2008)

Increased fruit and vegetable consumption has become a health priority in many countries. Therefore, data investigating the influence of different types of fruits and vegetables on serum antioxidant levels would be useful. The objective of the study was to assess the relationship between fruit and vegetable consumption and vitamin serum antioxidant concentrations. Specific fruit and vegetable groups are evaluated. A total of 3521 subjects (1487 men and 2034 women), aged 35-60 years, participating in the SU.VI.MAX cohort were included in this study. Blood samples of participants were analysed for $\beta$-carotene, vitamin $C$ and $\alpha$-tocopherol. Each subject had completed at least six dietary records during the first 2 years of the study. It was found that women had higher mean $\beta$-carotene and vitamin $C$ serum concentrations than men, but lower $\alpha$-tocopherol serum concentrations. Serum $\beta$-carotene and vitamin $C$ concentrations were positively correlated with consumption of both fruit and vegetables, as well as with most of the fruit and vegetable groups tested. These relationships persisted after adjustment for confounding factors. Regression analysis showed a linear dose-response relationship. Root vegetables and citrus fruits were particularly associated with $\beta$-carotene serum status as were citrus fruits for vitamin C. Fruit and vegetable consumption was either not or weakly associated with $\alpha$-tocopherol serum concentrations. These results describe antioxidant serum concentrations according to fruit and vegetable consumption in a large sample and support the findings of previous studies involving a more limited number of subjects.

Serum antioxidants: Vitamin: Fruit: Vegetables

There is evidence of an inverse relationship between fruit and vegetable consumption and the risk of CVD and cancers ${ }^{(1-5)}$. Consequently, promoting the consumption of at least five portions of fruits and vegetables $(400 \mathrm{~g})$ per $\mathrm{d}$ has become a national health priority in many countries ${ }^{(6)}$.

Several mechanisms have been proposed to explain this positive association, including an increased intake of antioxidant compounds that are widely found in fruits and vegetables. Trials in which antioxidant micronutrients were taken at high doses over long periods have not confirmed this potential beneficial effect ${ }^{(7-11)}$ and even suggested harmful effects ${ }^{(7,12,10)}$. However, at nutritional doses, antioxidant supplementation reduced the risk of cancer in men in the Supplementation with Antioxidant Vitamins and Minerals (SU.VI.MAX) study ${ }^{(13,14)}$ and reduced cancer risk and total mortality in the Linxian study ${ }^{(15,16)}$.

It is now considered that whole fruit and vegetables would confer a greater protection than that achieved by supplementation with a single component, through an interaction effect between several nutrients ${ }^{(17,18)}$.

Given the strong relationship between fruit and vegetable consumption and health, it would be useful to understand which serum antioxidants and what concentrations are associated with the recommended consumption of fruit and vegetables. In addition, among all fruit and vegetables, it should be clarified whether fruit, vegetables or specific foods from

Abbreviation: SU.VI.MAX, Supplementation with Antioxidant Vitamins and Minerals.

* Corresponding author: Professor Serge Hercberg, fax +3314838 89 31, email hercberg@cnam.fr 
these groups are more strongly associated with these serum concentrations.

Finally, few studies have examined the relationships between biological serum concentrations of antioxidants and fruit and vegetable consumption in European populations ${ }^{(19,20)}$. The objective of the present study was to investigate the relationship between fruit and vegetable (amount and type) consumption estimated by repeated $24 \mathrm{~h}$ records and vitamin serum concentrations, in a large sample of middle-aged adults from France.

\section{Methods}

\section{Subjects}

Subjects were participants of the SU.VI.MAX study, a randomised, double-blind, placebo-controlled, primary-prevention trial designed to evaluate the effect of a daily antioxidant supplementation at nutritional doses on the incidence of cancers and IHD. The design, methods and rationale of the SU.VI.MAX study have been reported elsewhere ${ }^{(14,21)}$. Briefly, 13017 participants (7876 women aged 35-60 years and 5141 men aged 45-60 years) were included in 1994-1995 with a planned follow-up of 8 years. To be included in the study, subjects should not have declared using vitamin supplements. Participants were invited annually for either a clinical or a biological examination and were asked to regularly provide information on health events and dietary habits.

The SU.VI.MAX study was approved by the Ethical Committee for Studies with Human Subjects of Paris-Cochin Hospital (CCPPRB no. 706) and the Comité National Informatique et Liberté (CNIL no. 334641).

\section{Dietary assessment}

The subjects were asked to provide a $24 \mathrm{~h}$ dietary record every 2 months, for a total of six records per year, so that weekdays, weekends and all seasons were covered. Information was collected via computerised questionnaires using the Minitel Telematic Network containing specific software. The Minitel was a small terminal widely used in France as an adjunct to the telephone at the beginning of the study. Participants were assisted by the conversational features of the software and used an instruction manual for coding food portions. This reference manual includes previously validated photographs ${ }^{(22)}$ of more than 250 foods (corresponding to 1000 generic foods) represented in three different portion sizes. Subjects could also choose from two intermediate or two extreme portions, for a total of seven different possible portion sizes.

\section{Blood sampling}

Blood samples were collected at enrolment (before supplementation) from participants, who had been fasting for $12 \mathrm{~h}$, in a mobile medical unit or a preventive health centre. All biochemical measurements were performed in only one laboratory for each nutrient being analysed. All measurements were carried out between November and April, which corresponds to a period of low fruit and vegetable consumption.

Blood samples for $\beta$-carotene and $\alpha$-tocopherol measurements were centrifuged immediately, then serum was frozen and kept at $-80^{\circ} \mathrm{C}$ until HPLC determination using Arnaud's method $^{(23)}$, with minor modifications. The HPLC system was a Biotek-Kontron (Montigny le Bretonneux, France) including a 525 gradient pump, a 402 Peltier Oven, a 465 auto sampler, a Geminyx data station and a 540 diode array detector.

To assess vitamin $\mathrm{C}$ concentration (dehydroascorbic acid and ascorbic acid), the serum was diluted (1:10) immediately in $10 \%$ metaphosphoric acid ${ }^{(24,25)}$ and kept frozen at $-80^{\circ} \mathrm{C}$ until determination by spectrofluorimetry ${ }^{(24)}$. A Technicon continuous flow analysis apparatus (Bayer-Technicon, Pittsburgh, PA, USA) that was equipped with a RF-530 Shimatzu fluorescence detector (Shimatzu Corporation, Kyoto, Japan) was used.

The laboratory quality insurance included analysis of serum from standard pools with each run and, if available, international standards (markers ProBioQual). CV were determined by measuring concentrations in aliquots five times on the same day and on ten different days: $9.02 \%$ for $\beta$-carotene; $3.52 \%$ for vitamin C; $3.54 \%$ for $\alpha$-tocopherol. Total cholesterol and TAG were measured by enzymic methods (Technicon DAX, Tarrytown, NY, USA).

\section{Other data collection}

Information about physical activity (irregular, $<1 \mathrm{~h}$ walking/d, $\geq 1 \mathrm{~h}$ walking/d), smoking status (non-smoker, former smoker, current smoker) and education level (primary school, high school, university or equivalent) was self-reported by participants on a questionnaire at enrolment. BMI was calculated using weight and height measured during a clinical examination 1 year after enrolment. When these measures were not available (n 482), self-reported weight and height from the enrolment questionnaire were used.

\section{Inclusion criteria}

A sub-sample of the population of 8280 subjects had $\beta$-carotene, vitamin $\mathrm{C}$ and $\alpha$-tocopherol serum concentrations measured at inclusion. Subjects with at least six or more $24 \mathrm{~h}$ records completed in the 2 years following inclusion were included for the present analyses ( $n$ 4195). An additional 21 subjects were excluded because more than one-third of their $24 \mathrm{~h}$ records were lower than $2090 \mathrm{~kJ}$ (women) or $3334 \mathrm{~kJ}$ (men), leaving 4174 subjects.

Fruit and vegetable consumption can vary greatly according to season. Therefore, participants were selected if at least onethird of their reported $24 \mathrm{~h}$ records were from the low season (November to April) and another third from the high season (May to October) of fruit and vegetable intakes, leaving 3861 individuals. A total of 360 subjects were further excluded because at least one adjustment variable was missing, leaving a total of 1487 men and 2034 women included in the present analysis.

\section{Statistical methods}

Fruits and vegetables from composite dishes were included, but potatoes as well as dried fruits and legumes were excluded. Subgroups of fruit and vegetables as described in Table 1 were investigated. However, fruit and vegetable groups in which intake levels were too small to be significant 
Table 1. Groups of fruits and vegetables

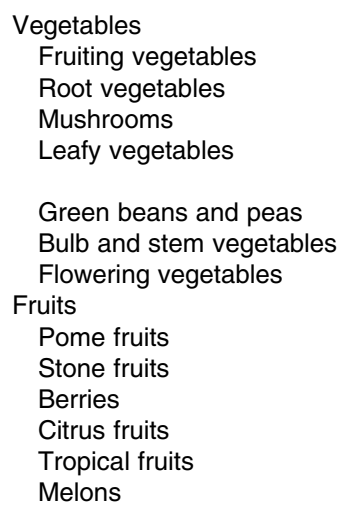

(e.g. cabbage) were not considered. Groups of fruit mainly consumed during the summer (i.e. stone fruit, melons, berries) were not studied. Their consumption is not close enough to the blood sampling period and therefore would not be able to explain serum antioxidant concentrations measured.

The relationship between antioxidants and all fruit and vegetables was assessed using Spearman's rank correlation. $\beta$-Carotene and $\alpha$-tocopherol concentrations were adjusted on plasma cholesterol and TAG concentration using the standard value of $5.18 \mathrm{mmol} / \mathrm{l}$ for cholesterol and $1.25 \mathrm{mmol} / \mathrm{l}$ for $\mathrm{TAG}^{(26,27)}$. Fruit and vegetables were adjusted on energy intake $^{(26)}$. Generalised linear models were used to perform multivariate analyses. In the multivariate analyses, logarithmic transformation of the distribution was used because of skewed distribution of serum antioxidant concentrations. Adjusted geometric means of serum antioxidants are presented for each quintile of fruit and vegetable groups. Trend tests using fruit and vegetable intakes as continuous variable were performed. The multivariate analyses were adjusted for potential predictors of antioxidant concentration: sex; age at inclusion (continuous); BMI (continuous); physical activity (three categories); smoking status (three categories); education level (three categories); energy intake (continuous); alcohol consumption (continuous); month of blood sampling (one category for each month); cholesterol and TAG concentrations (continuous). When analysing groups of fruit or vegetables, all other fruit or vegetables were included in the model. We used four different types of models. In addition to adjusted variables, the first model included 'fruit and vegetables', the second, 'fruit' and 'vegetables', the third, 'fruit juices', 'fruit without juices' and 'vegetables' and the last included all subgroups of vegetables. Statistical analyses were performed using SAS software (The SAS Institute Inc., Cary, NC, USA).

\section{Results}

Characteristics of selected men and women at baseline are presented in Table 2. As expected by the sampling method, mean age was higher in men than women. Men had a higher mean BMI, higher physical activity and a lower educational level than women. The percentage of current smokers was similar in both groups. Women consumed less energy and less alcohol. Women consumed $24 \mathrm{~g} / \mathrm{d}$ more fruit and $15 \mathrm{~g} / \mathrm{d}$ more vegetables than men after energy intake adjustment. The most consumed vegetables were fruiting vegetables and root vegetables for both men and women, while the most consumed fruit were pome fruit and stone fruit. Fruit juices represented $17.0 \%$ of fruit intake in men and $17.8 \%$ in women. Quintiles medians of crude intake are shown in Table 3.

Women had higher $\beta$-carotene and vitamin $\mathrm{C}$ serum concentrations than men, but lower $\alpha$-tocopherol serum concentration (Table 1). Serum $\beta$-carotene and vitamin $C$ concentrations were correlated with fruit and vegetable consumption, as well as with most of the food groups tested (Table 4). In contrast, serum $\alpha$-tocopherol correlated poorly with a few of the food categories tested. Correlations for $\beta$-carotene ranged from -0.03 to 0.25 and were correlated with both vegetables $(r 0.24)$ and fruit $(r 0 \cdot 18)$. Root vegetables and citrus fruit were particularly correlated with $\beta$-carotene. Correlations for vitamin $C$ ranged from 0.03 to 0.34 and were greater for fruit than for vegetables. Vitamin $\mathrm{C}$ correlated with fruit as well as with fruit + fruit juices and with citrus fruit. Correlation for $\alpha$-tocopherol ranged from $0 \cdot 00$ to $0 \cdot 09$. Finally, $\alpha$-tocopherol was significantly but poorly correlated with vegetable $(0 \cdot 05)$ and fruit (0.04) consumption. Correlations with vegetable groups were mostly non-significant, with the exception of leafy vegetables, bulb and stem vegetables and citrus fruit.

After adjusting for confounding factors, higher fruit and vegetable consumption was associated with higher serum concentrations of $\beta$-carotene and vitamin $C$ with a linear doseeffect relationship and significant $P$ for trend (Table 5). Specifically, the serum concentration of $\beta$-carotene was related to vegetables in general and to the root, leafy and fruiting vegetable groups as well as green beans and peas. In addition, fruit, fruit + juices and particularly pome and citrus fruit were related to $\beta$-carotene status. Serum vitamin $C$ concentrations were related to the same food products with the addition of tropical fruits and fruit juices and the exclusion of green beans and peas. Vitamin $\mathrm{C}$ was more strongly associated with fruit than with vegetables. On the other hand, no significant relationship was found for $\alpha$-tocopherol. Analysis of adjusted geometric means of antioxidant concentration suggested a linear dose-response relationship for all groups of fruit and vegetables associated with antioxidants. 
Table 2. Characteristics of the study population $\dagger$

(Mean values and standard deviations)

\begin{tabular}{|c|c|c|c|c|c|c|c|}
\hline & \multicolumn{3}{|c|}{ Men $(n 1487)$} & \multicolumn{3}{|c|}{ Women (n 2034) } & \multirow[b]{2}{*}{$P$} \\
\hline & Mean & SD & $\%$ & Mean & SD & $\%$ & \\
\hline Age (years) & $52 \cdot 1$ & 4.7 & & $47 \cdot 1$ & 6.7 & & *** \\
\hline BMI $\left(\mathrm{kg} / \mathrm{m}^{2}\right)$ & $25 \cdot 3$ & 3.0 & & $23 \cdot 0$ & $3 \cdot 6$ & & *** \\
\hline Physical activity & & & & & & & 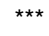 \\
\hline Irregular & & & $24 \cdot 0$ & & & 26.5 & \\
\hline$<1 \mathrm{~h}$ walking/d & & & 23.9 & & & $35 \cdot 3$ & \\
\hline$\geq 1 \mathrm{~h}$ walking $/ \mathrm{d}$ & & & $52 \cdot 1$ & & & 38.2 & \\
\hline Smoking status & & & & & & & 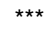 \\
\hline Non-smoker & & & 34.5 & & & $57 \cdot 7$ & \\
\hline Former smoker & & & $51 \cdot 6$ & & & $29 \cdot 3$ & \\
\hline Current smoker & & & 13.9 & & & $13 \cdot 1$ & \\
\hline Education level & & & & & & & $* * *$ \\
\hline Primary school & & & $24 \cdot 3$ & & & $18 \cdot 4$ & \\
\hline High school & & & $37 \cdot 0$ & & & 40.1 & \\
\hline University or equivalent & & & 38.7 & & & 41.5 & \\
\hline Energy intake $(\mathrm{MJ} / \mathrm{d})$ & $10 \cdot 40$ & 2.36 & & 7.78 & 1.86 & & *** \\
\hline Ethanol intake $(\mathrm{g} / \mathrm{d})$ & 29.5 & 23.5 & & 11.0 & $13 \cdot 2$ & & 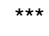 \\
\hline Vegetables + fruits + juices $(\mathrm{g} / \mathrm{d})$ & 416 & 182 & & 456 & 156 & & *** \\
\hline Vegetables & 198 & 87 & & 213 & 80 & & 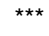 \\
\hline Fruiting vegetables & 41 & 35 & & 46 & 28 & & $\star * \star \star$ \\
\hline Root vegetables & 38 & 30 & & 41 & 27 & & 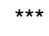 \\
\hline Leafy vegetables & 30 & 24 & & 34 & 25 & & $* \star *$ \\
\hline Green beans and peas & 27 & 25 & & 26 & 22 & & \\
\hline Bulb and stem vegetables & 21 & 19 & & 23 & 16 & & * \\
\hline Flowering vegetables & 14 & 20 & & 15 & 20 & & * \\
\hline Mushrooms & 8 & 11 & & 8 & 10 & & \\
\hline Other vegetables & & & & & & & \\
\hline Fruits + fruit juices & 218 & 144 & & 242 & 118 & & $* \star \star *$ \\
\hline Fruits & 180 & 128 & & 199 & 104 & & *** \\
\hline Pome fruits & 77 & 79 & & 77 & 57 & & \\
\hline Stone fruitsł & 27 & 36 & & 31 & 33 & & *** \\
\hline Berriesł & 22 & 32 & & 26 & 26 & & $* \star \star$ \\
\hline Citrus fruits & 23 & 33 & & 28 & 28 & & 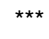 \\
\hline Tropical fruits & 19 & 30 & & 22 & 25 & & *** \\
\hline Melon $\ddagger$ & 12 & 21 & & 14 & 20 & & 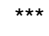 \\
\hline Fruit juices & 37 & 66 & & 43 & 57 & & *** \\
\hline Plasma antioxidant levels & Median & $\begin{array}{l}\text { Upper boundary of } \\
\text { 1st and 3rd quartile }\end{array}$ & & Median & $\begin{array}{l}\text { Upper boundary of } \\
\text { 1st and 3rd quartile }\end{array}$ & & \\
\hline$\beta$-Carotene $(\mu \mathrm{mol} / \mathrm{l})$ & 0.33 & $0.18-0.54$ & & 0.44 & $0.26-0.69$ & & 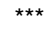 \\
\hline Vitamin C $(\mu \mathrm{mol} / \mathrm{l})$ & $49 \cdot 4$ & $34 \cdot 7-61 \cdot 7$ & & $58 \cdot 4$ & $46 \cdot 4-70 \cdot 4$ & & *** \\
\hline$\alpha$-Tocopherol $(\mu \mathrm{mol} / \mathrm{l})$ & 27.5 & $24 \cdot 1-31 \cdot 7$ & & $28 \cdot 2$ & $24.5-32.4$ & & ** \\
\hline
\end{tabular}

$\chi^{2}$ for qualitative variables and $t$ test for quantitative variables.

Fruit and vegetable consumption is adjusted on energy.

Plasma antioxidant level is adjusted on cholesterol and TAG.

Values were significantly different: ${ }^{*} P<0.05 ;{ }^{*} P<0.01$; ${ }^{\star \star \star} P<0.001$.

†For details of subjects and procedures, see Methods.

$\ddagger$ Not included in the analysis on the relationship with antioxidants.

\section{Discussion}

The present results indicate that intakes of fruit and vegetables are moderately correlated with serum concentrations of $\beta$-carotene and vitamin $\mathrm{C}$ but not with $\alpha$-tocopherol. Other factors influencing antioxidant concentrations, such as sex, age, smoking status, season, dietary intake and location of residence, have been identified in previous analyses from the SU.VI.MAX study ${ }^{(28,29)}$.

In the current study, mean fruit and vegetable intakes for both sexes were higher than described in other studies performed on the French population ${ }^{(30-32)}$. This may be partly due to the sample selection, as participants who completed at least six dietary records might be specifically interested in health and diet and may thus show a better dietary profile.
The participants' higher level of education may also partly explain high fruit and vegetable consumption ${ }^{(33)}$.

A number of studies have examined the correlation between fruit and vegetable intakes and plasma nutrients. $\beta$-Carotene was consistently found to be associated with intakes of fruit and/or vegetables in a number of observational ${ }^{(34-41)}$ and intervention $^{(42-49)}$ studies. However, Al Delaimy et al. ${ }^{(19,50)}$ suggested that the correlation of plasma $\beta$-carotene with fruit and vegetable intake was low compared with other carotenoids. Although at the lower end of the range, the correlation coefficients observed in the present study (fruit + vegetables + juices: $r$ 0.25; fruit: $r 0.19$; vegetables: $r 0.24$ ) were comparable with those found in previous observational studies, ranging from 0.17 to 0.45 for fruit and vegetables, from 0.18 to 0.45 for fruit and from 0.18 to 0.34 for 
Table 3. Quintiles medians of crude intake

\begin{tabular}{|c|c|c|c|c|c|c|c|c|c|c|}
\hline & \multicolumn{5}{|c|}{ Men ( $n$ 1487) } & \multicolumn{5}{|c|}{ Women ( $n$ 2034) } \\
\hline & \multicolumn{5}{|c|}{ Quintile of consumption } & \multicolumn{5}{|c|}{ Quintile of consumption } \\
\hline & Lowest & 2 & 3 & 4 & Highest & Lowest & 2 & 3 & 4 & Highest \\
\hline Vegetables + fruits + juices & 232 & 341 & 439 & 542 & 713 & 230 & 332 & 407 & 494 & 644 \\
\hline Vegetables & 110 & 160 & 204 & 253 & 336 & 105 & 153 & 192 & 234 & 308 \\
\hline Fruiting vegetables & 12 & 32 & 50 & 69 & 106 & 14 & 32 & 48 & 66 & 98 \\
\hline Root vegetables & 9 & 22 & 36 & 51 & 81 & 9 & 22 & 32 & 46 & 75 \\
\hline Leafy vegetables & 6 & 17 & 27 & 41 & 66 & 7 & 17 & 28 & 40 & 64 \\
\hline Green beans and peas & 2 & 12 & 22 & 36 & 63 & 2 & 11 & 20 & 32 & 53 \\
\hline Bulb and stem vegetables & 5 & 12 & 19 & 28 & 48 & 5 & 10 & 17 & 25 & 43 \\
\hline Flowering vegetables & 0 & 1 & 4 & 19 & 42 & 0 & 1 & 6 & 19 & 39 \\
\hline Mushrooms & 0 & 2 & 5 & 10 & 23 & 0 & 1 & 4 & 9 & 20 \\
\hline Fruits + fruit juices & 70 & 151 & 218 & 294 & 441 & 81 & 152 & 210 & 276 & 381 \\
\hline Fruits & 55 & 117 & 177 & 250 & 369 & 61 & 121 & 168 & 227 & 321 \\
\hline Pome fruits & 9 & 36 & 66 & 107 & 192 & 11 & 34 & 57 & 88 & 145 \\
\hline Citrus fruits & 0 & 6 & 14 & 27 & 59 & 1 & 10 & 19 & 33 & 58 \\
\hline Tropical fruits & 0 & 2 & 11 & 25 & 57 & 0 & 4 & 12 & 24 & 52 \\
\hline Fruit juices & 0 & 0 & 13 & 41 & 130 & 0 & 0 & 18 & 45 & 117 \\
\hline
\end{tabular}

${ }^{*}$ For details of subjects and procedures, see Methods.

vegetables, using either Pearson or Spearman correlation coefficients. In the present investigation, fruits were found to have comparable associations with serum concentrations of $\beta$-carotene rather than vegetables. These results are in agreement with those of Drewnowski et al. ${ }^{(36)}$, who showed similar correlation coefficients for fruit and vegetables. However, they contrast with previous studies ${ }^{(35,37,41)}$, which found greater correlation coefficients for fruit than for vegetables. In the current study, fruit juices had a weak or no association with serum concentrations according to the regression analysis. Few authors have also investigated the importance of fruit juice contributing to nutrient serum concentrations. Two studies found a limited positive ${ }^{(37,38)}$ association and one study reported an inverse association ${ }^{(41)}$. In addition, McEligot et al. ${ }^{(51)}$ found no significant difference in serum values of $\beta$-carotene between subjects consuming juice and those not consuming any juice.

Only a few studies looked at possible differences in serum nutrient concentrations for particular fruit and vegetables. In the present study, the root vegetables category, which includes carrots, was shown to be specifically associated with serum concentrations of $\beta$-carotene. In addition, there was a stronger association for citrus and pome fruit compared with tropical fruit. Similarly, the vegetables most associated with $\beta$-carotene status were root vegetables ${ }^{(19,50)}$ or more specifically carrots $^{(35,40)}$, in subjects with a wide variety and regular consumption of vegetables and fruits. In another study, both carrots and tomatoes were associated with $\beta$-carotene status $^{(52)}$, whereas Jansen et al. ${ }^{(37)}$ showed the specific importance of tomatoes and cabbages. It should be noted

Table 4. Spearman's correlation coefficients and significance for the correlation between plasma antioxidant concentration adjusted for cholesterol and TAG and intake of vegetables, fruits and juices adjusted on energy $(n 3521) \dagger$

\begin{tabular}{|c|c|c|c|c|c|c|}
\hline & \multicolumn{2}{|c|}{$\beta$-Carotene } & \multicolumn{2}{|c|}{ Vitamin C } & \multicolumn{2}{|c|}{$\alpha$-Tocopherol } \\
\hline & $r$ & $P$ & $r$ & $P$ & $r$ & $P$ \\
\hline Vegetables + fruits + juices & 0.25 & $\star \star \star ~$ & 0.34 & 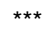 & 0.06 & ** \\
\hline Vegetables & 0.24 & $\star \star \star$ & 0.16 & 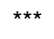 & 0.05 & ** \\
\hline Fruiting vegetables & $0 \cdot 10$ & 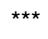 & 0.11 & 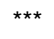 & 0.03 & \\
\hline Root vegetables & 0.22 & 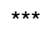 & 0.12 & $* * *$ & 0.04 & \\
\hline Leafy vegetables & 0.13 & 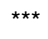 & 0.10 & 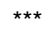 & 0.09 & *** \\
\hline Green beans and peas & 0.09 & $\star * *$ & 0.04 & * & -0.001 & \\
\hline Bulb and stem vegetables & 0.14 & $\star * *$ & 0.07 & $\star * *$ & 0.04 & * \\
\hline Flowering vegetables & 0.11 & *** & 0.08 & *** & 0.01 & \\
\hline Mushrooms & -0.03 & & 0.03 & & 0.02 & \\
\hline Fruits + fruit juices & 0.18 & 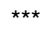 & 0.34 & $\star \star * *$ & 0.04 & * \\
\hline Fruits & 0.19 & $\star \star \star$ & 0.29 & $* * *$ & 0.04 & * \\
\hline Pome fruits & 0.15 & 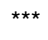 & 0.19 & 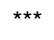 & 0.03 & \\
\hline Citrus fruits & 0.16 & $\star * *$ & 0.28 & $* * *$ & 0.04 & * \\
\hline Tropical fruits & 0.11 & 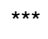 & 0.17 & 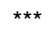 & 0.02 & \\
\hline Fruit juices & 0.04 & * & 0.19 & 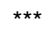 & 0.02 & \\
\hline
\end{tabular}

Values were significantly different: ${ }^{\star} P<0.05 ;{ }^{\star \star} P<0.01 ;{ }^{* \star *} P<0.001$.

$\dagger$ For details of subjects and procedures, see Methods. 
Table 5. Adjusted geometric means of plasma levels within quintiles of intake $(n 3521)^{*}$

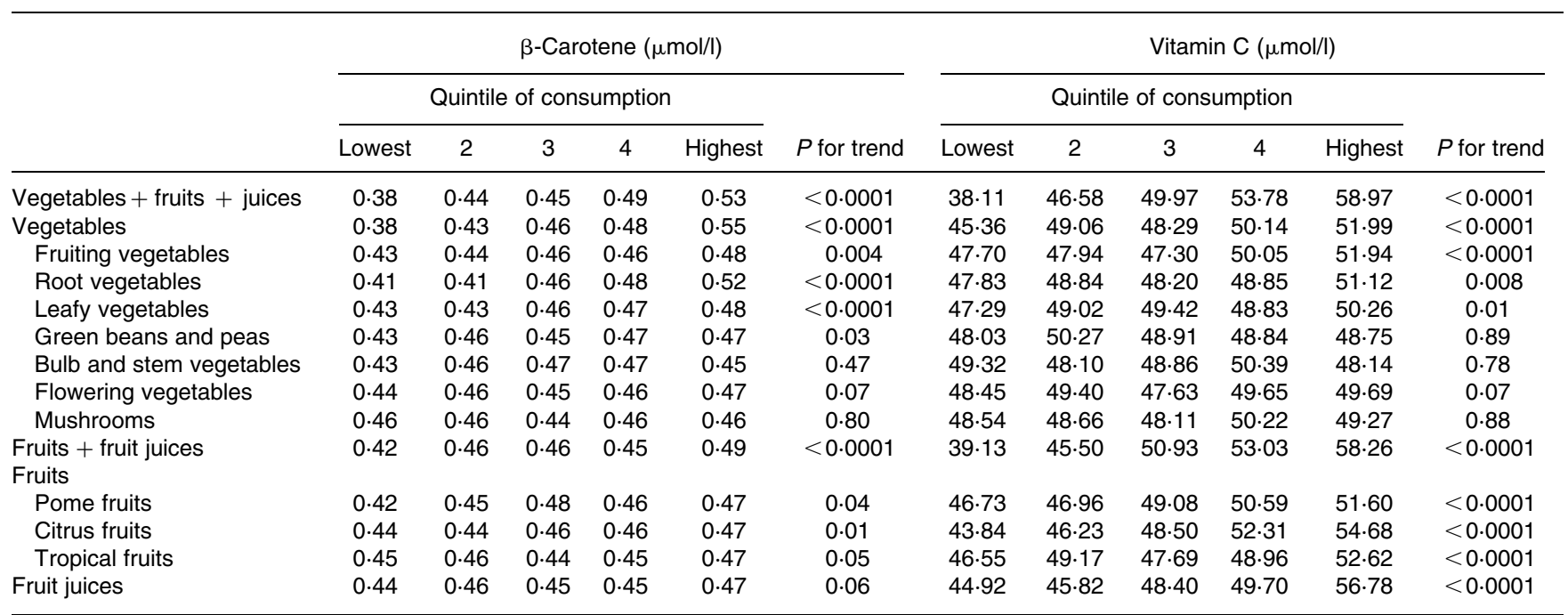

Adjusted for gender, age, BMI, physical activity, smoking status, education level, energy intake, alcohol consumption, blood sampling month, cholesterol and TAG.

Fruit and vegetable groups are adjusted for all other groups.

* For details of subjects and procedures, see Methods.

that only fruits consumed in autumn and winter were considered in the current study, as blood sampling was carried out exclusively during this period. Therefore, the association between berries, stone fruit and melons with antioxidant serum concentrations could not be investigated. In addition, it is likely that the association with fruit or vegetables mostly consumed during these periods, such as citrus fruit, is overestimated.

A possible increase of cancer risk with an antioxidant supplementation has been emphasised in intervention trials ${ }^{(7,10)}$. However, a concentration of $0.53 \mu \mathrm{mol} / \mathrm{l}$ found in the present study for $\beta$-carotene is far lower than concentrations of $5.6 \mu \mathrm{mol} / \mathrm{l}^{(7)}$ or $3.9 \mu \mathrm{mol} / \mathrm{l}^{(10)}$ observed in these trials where high doses of pharmacological supplements were given.

The relationship found between vitamin $\mathrm{C}$ status and usual consumption of fruit and vegetables has been consistently found in observational studies ${ }^{(34,36,38,53)}$. The correlation coefficient found for vegetables + fruit + juices $(r 0.28)$ is similar to the value found by Drewnowski et al. ${ }^{(36)}$ for fruit and vegetables $(r$ 0.29), but lower than the one found by Block et al. ${ }^{(34)}(r 0.59)$. These results are supported by interventional studies, where subjects consuming increased amounts of fruit and vegetables had higher concentrations of plasma vitamin $\mathrm{C}^{(43-46,49)}$. Fruits were found to be more associated with serum concentrations of vitamin $\mathrm{C}$ than vegetables, as observed in previous studies ${ }^{(36,53)}$. Citrus fruits were more strongly associated with serum concentrations of vitamin $\mathrm{C}$ in the present study, whereas pome fruit, tropical fruit and fruit juices showed lower correlation coefficients. However, the regression analysis indicated that all fruits and fruit juices analysed highly contributed to antioxidant concentrations. Of the different vegetable groups, fruiting, leafy and root vegetables provided the highest contribution. Results from the Su et al. study $^{(39)}$ supported the contribution of salad consumption, which is an important component of the leafy vegetable group.
In the present study, vitamin $\mathrm{C}$ concentrations were more strongly associated with overall fruit and vegetable intake ( $r$ 0.28) than $\beta$-carotene concentrations ( $r$ 0.20). These results are slightly different from those of Drewnowki et al. ${ }^{(36)}$, who reported a higher correlation between energy adjusted fruit and vegetable intake and $\beta$-carotene $(r 0 \cdot 36)$ than with vitamin $\mathrm{C}$ concentrations $(r$ 0.29) in another French population. However, the current findings support the results from the Block et al. ${ }^{(34)}$ study, in which vitamin $\mathrm{C}$ was found to be considerably more associated with fruit and vegetable intakes $(r 0.59)$ than $\beta$-carotene $(r$ 0.35). Intervention studies have shown a greater association between fruit and vegetable intakes and vitamin $C$ concentrations compared with $\beta$-carotene ${ }^{(43,49)}$ or have at least shown a similar association ${ }^{(45)}$. However, the fruit and vegetables category cannot be considered in its entirety, since correlations can vary greatly between these two foods. In the present study, vitamin $\mathrm{C}$ was consistently shown to be related to fruit intakes compared with $\beta$-carotene. On the other hand, $\beta$-carotene was found to be more associated with vegetable intakes compared with vitamin C. Therefore, the proportion of fruit in the diet when compared with vegetables might significantly affect the results.

Fruit and vegetables as well as some fruit and vegetable groups were shown to be significantly associated with serum $\alpha$-tocopherol. However, these relationships were very weak and probably significant due to the large number of subjects. Although fruits and vegetables are sources of these two antioxidants, their contribution to serum concentrations is negligible: the main sources of $\alpha$-tocopherol are oils, nuts, seeds and wholegrain cereals. Thus, the correlation observed between leafy vegetables and serum $\alpha$-tocopherol may be mainly explained by the dressing that is often added to this type of food. These findings confirm the results of observational $^{(34,35)}$ and intervention ${ }^{(42,43,45,46,49)}$ studies on $\alpha$-tocopherol, which included a relatively small number of subjects.

The present study included a very large sample of subjects from a free-living population and with a large diet diversity, 
even though subjects were recruited on a voluntary basis ${ }^{(21)}$. This is an advantage when compared with other studies realised in this field, which often included a relatively limited number of individuals. In addition, the design of the present study provides precision of both biochemical and diet measurements. The evaluation of antioxidant serum concentrations were all performed in one laboratory, in the morning, and in fasting subjects, therefore reducing the variability of measures due to methodology and diurnal variations ${ }^{(54)}$. Assessing fruit and vegetable intake is a frequently encountered problem. Studies investigating the relationships between serum concentrations of antioxidants and diet most often use $\mathrm{FFQ}^{(35,37,40,41)}$ and sometimes a single $24 \mathrm{~h}$ recall $^{(39)}$. Al Delaimy et al. ${ }^{(50)}$ concluded that fruit and vegetable intakes assessed by $24 \mathrm{~h}$ recalls were generally better able to predict plasma carotenoids than FFQ on an ecological concentration. In addition, three $24 \mathrm{~h}$ recalls provide a particularly good estimation of the diet, when compared with other methods if subjects are well educated ${ }^{(55)}$. The present study includes well-educated volunteers, with about two-thirds of subjects having achieved high school. Therefore, the use of at least six $24 \mathrm{~h}$ records per person provides added precision and validity.

In this supplementation trial, diet assessment followed blood sampling. Consequently, the timing between intake and serum variables is not consistent with a cause-andeffect relationship. However, in the present study we aimed to evaluate the relationship between usual diet and serum concentrations of antioxidants. In this cohort, diet has been shown to be very stable over the years (data not shown), and diet measured over 2 years is therefore representative of the usual diet. Furthermore, blood sampling has been performed over a period of 7 months, corresponding to autumn and winter seasons, and was compared with usual fruit and vegetable consumption over the year. Fruit and vegetable groups with high seasonal variation of consumption are therefore unlikely to be related to antioxidant concentrations in the blood sampling period. Fruit and vegetables mainly consumed in summer were therefore not considered. However, consumption of the other fruit and vegetable groups studied was relatively stable over the period of blood sampling (data not shown), suggesting that the correlation measured is representative of the relationship with usual fruit and vegetable consumption in the autumn/winter period. The fact that the blood sampling period does not fully cover the dietary measurement period could partly explain why observed correlations are lower than in previous studies. Finally, the single blood sample available in the present study did not allow us to take into account day to day variation in antioxidant levels.

In conclusion, serum concentrations of $\beta$-carotene and vitamin $\mathrm{C}$ were associated with fruit and vegetable intake in the current study population. Vitamin $\mathrm{C}$ serum concentrations were particularly associated with fruit intakes. These results support the findings of other studies, including a more limited number of subjects, and investigating the relationship between nutrient serum concentrations and fruit and vegetable intakes. However, correlations found in the present study may be too weak to support the use of $\beta$-carotene and vitamin $\mathrm{C}$ serum concentrations as biomarkers of dietary intake or the validation of a dietary assessment method but changes in serum antioxidants could potentially be used to validate self-reported changes in fruit and vegetable intake in intervention studies ${ }^{(46)}$. The specific importance of root vegetables and citrus fruit for $\beta$-carotene status was emphasised in the present study, as well as the importance of citrus fruit for vitamin C. Variations in associations between specific groups of fruit or vegetables and serum concentrations of antioxidants could be taken into account when making public health recommendations.

\section{Acknowledgements}

None of the authors had any personal or financial conflict of interest. We would like to thank Stacie Yung for reviewing and editing the manuscript. The SU.VI.MAX project received funds from the Direction Générale de la Santé, the Ministère de la Santé and the Institut Virtuel de Recherche en Santé Publique (groupe cohorte) INSERM.

\section{References}

1. Lock K, Pomerleau J, Causer L, Altmann DR \& McKee M (2005) The global burden of disease attributable to low consumption of fruit and vegetables: implications for the global strategy on diet. Bull World Health Organ 83, 100-108.

2. Dauchet L, Amouyel P, Hercberg S \& Dallongeville J (2006) Fruit and vegetable consumption and risk of coronary heart disease: a meta-analysis of cohort studies. $J$ Nutr 136, $2588-2593$.

3. He FJ, Nowson CA \& MacGregor GA (2006) Fruit and vegetable consumption and stroke: meta-analysis of cohort studies. Lancet 367, 320-326.

4. Dauchet L, Amouyel P \& Dallongeville J (2005) Fruit and vegetable consumption and risk of stroke: a meta-analysis of cohort studies. Neurology 65, 1193-1197.

5. WCRF/AICR (2007) Food, Nutrition, Physical Activity and Prevention of Cancer: A Global Perspective. London: World Cancer Research Fund and Washington, DC: American Institute of Cancer Research.

6. World Health Organization (2003) Fruit and vegetable promotion initiative. Report of the meeting held in Geneva, 25-27 August 2003. Geneva, Switzerland: World Health Organization.

7. ATBC (1994) The effect of vitamin $E$ and beta carotene on the incidence of lung cancer and other cancers in male smokers. The Alpha-Tocopherol, Beta Carotene Cancer Prevention Study Group. N Engl J Med 330, 1029-1035.

8. Hennekens CH, Buring JE, Manson JE, et al. (1996) Lack of effect of long-term supplementation with beta carotene on the incidence of malignant neoplasms and cardiovascular disease. $N$ Engl J Med 334, 1145-1149.

9. Lee IM, Cook NR, Manson JE, Buring JE \& Hennekens CH (1999) Beta-carotene supplementation and incidence of cancer and cardiovascular disease: the Women's Health Study. J Natl Cancer Inst 91, 2102-2106.

10. Omenn GS, Goodman GE, Thornquist MD, et al. (1996) Effects of a combination of beta carotene and vitamin A on lung cancer and cardiovascular disease. $N$ Engl J Med 334, 1150-1155.

11. Vivekananthan DP, Penn MS, Sapp SK, Hsu A \& Topol EJ (2003) Use of antioxidant vitamins for the prevention of cardiovascular disease: meta-analysis of randomised trials. Lancet 361, 2017-2023. 
12. Bjelakovic G, Nikolova D, Gluud LL, Simonetti RG \& Gluud C (2007) Mortality in randomized trials of antioxidant supplements for primary and secondary prevention: systematic review and meta-analysis. JAMA 297, 842-857.

13. Galan P, Briancon S, Favier A, et al. (2005) Antioxidant status and risk of cancer in the SU.VI.MAX study: is the effect of supplementation dependent on baseline levels? Br J Nutr 94, $125-132$.

14. Hercberg S, Galan P, Preziosi P, Bertrais S, Mennen L, Malvy D, Roussel AM, Favier A \& Briancon S (2004) The SU.VI.MAX Study: a randomized, placebo-controlled trial of the health effects of antioxidant vitamins and minerals. Arch Intern Med 164, 2335-2342.

15. Blot WJ, Li JY, Taylor PR, et al. (1993) Nutrition intervention trials in Linxian, China: supplementation with specific vitamin/ mineral combinations, cancer incidence, and disease-specific mortality in the general population. $J$ Natl Cancer Inst $\mathbf{8 5}$, $1483-1492$.

16. Li JY, Taylor PR, Li B, et al. (1993) Nutrition intervention trials in Linxian, China: multiple vitamin/mineral supplementation, cancer incidence, and disease-specific mortality among adults with esophageal dysplasia. J Natl Cancer Inst 85, 1492-1498.

17. Norman HA, Go VL \& Butrum RR (2004) Review of the international research conference on food, nutrition, and cancer, 2004. J Nutr 134, 3391S-3393S.

18. Donaldson MS (2004) Nutrition and cancer: a review of the evidence for an anti-cancer diet. Nutr J 3,19.

19. Al Delaimy WK, Ferrari P, Slimani N, et al. (2005) Plasma carotenoids as biomarkers of intake of fruits and vegetables: individual-level correlations in the European Prospective Investigation into Cancer and Nutrition (EPIC). Eur J Clin Nutr 59, 1387-1396.

20. Ferrari P, Al Delaimy WK, Slimani N, et al. (2005) An approach to estimate between- and within-group correlation coefficients in multicenter studies: plasma carotenoids as biomarkers of intake of fruits and vegetables. Am J Epidemiol 162, 591-598.

21. Hercberg S, Preziosi P, Briancon S, Galan P, Triol I, Malvy D, Roussel AM \& Favier A (1998) A primary prevention trial using nutritional doses of antioxidant vitamins and minerals in cardiovascular diseases and cancers in a general population: the SU.VI.MAX study - design, methods, and participant characteristics. SUpplementation en VItamines et Mineraux AntioXydants. Control Clin Trials 19, 336-351.

22. Le Moullec N, Deheeger M, Preziosi P, Monteiro P, Valeix P, Rolland-Cachera MF, Potier De Courcy G, Christides JP, Galan P \& Hercberg S (1996) Validation du manuel-photos utilisé pour l'enquête alimentaire de l'étude SU.VI.MAX. (Validation of the photo manual used for the collection of dietary data in the SU.VI.MAX study). Cah Nut Diét 31, 158-164.

23. Arnaud J, Fortis I, Blachier S, Kia D \& Favier A (1991) Simultaneous determination of retinol, alpha-tocopherol and beta-carotene in serum by isocratic high-performance liquid chromatography. J Chromatogr 572, 103-116.

24. Bourgeois CF, Chartois RR, Counstans MF \& George PR (1989) Automated determination of vitamin C in foodstuffs and biological tissues. Analysis 9, 519-525.

25. Margolis SA \& Duewer DL (1996) Measurement of ascorbic acid in human plasma and serum: stability, intralaboratory repeatability, and interlaboratory reproducibility. Clin Chem 42, $1257-1262$.

26. Willett WC (1998) Nutritional Epidemiology. Oxford: Oxford University Press.

27. Jordan P, Brubacher D, Moser U, Stahelin HB \& Gey KF (1995) Vitamin $\mathrm{E}$ and vitamin A concentrations in plasma adjusted for cholesterol and triglycerides by multiple regression. Clin Chem 41, 924-927.
28. Faure H, Preziosi P, Roussel AM, Bertrais S, Galan P, Hercberg $S$ \& Favier A (2006) Factors influencing blood concentration of retinol, alpha-tocopherol, vitamin $\mathrm{C}$, and beta-carotene in the French participants of the SU.VI.MAX trial. Eur J Clin Nutr 60, 706-717.

29. Galan P, Viteri FE, Bertrais S, et al. (2005) Serum concentrations of beta-carotene, vitamins $\mathrm{C}$ and $\mathrm{E}$, zinc and selenium are influenced by sex, age, diet, smoking status, alcohol consumption and corpulence in a general French adult population. Eur J Clin Nutr 59, 1181-1190.

30. Guilbert P \& Perrin-Escalon H (2003) Barométre Santé Nutrition 2002 (2002 Health and Nutrition Barometer). Saint-Denis, France: INPES.

31. Volatier JL, Maffre J \& Couvreur A (2000) Enquéte Individuelle et National sur les Consommations Alimentaires (INCA) (National Survey of Individual Food Consumption). Paris: Tec \& Doc Lavoisier.

32. Touvier M, Kesse E, Volatier JL, Clavel-Chapelon F \& Boutron-Ruault MC (2006) Dietary and cancer-related behaviors of vitamin/mineral dietary supplement users in a large cohort of French women. Eur J Nutr 45, 205-214.

33. Irala-Estevez JD, Groth $\mathrm{M}$, Johansson $\mathrm{L}$, Oltersdorf $\mathrm{U}$, Prattala R \& Martinez-Gonzalez MA (2000) A systematic review of socio-economic differences in food habits in Europe: consumption of fruit and vegetables. Eur J Clin Nutr 54, 706-714.

34. Block G, Norkus E, Hudes M, Mandel S \& Helzlsouer K (2001) Which plasma antioxidants are most related to fruit and vegetable consumption? Am J Epidemiol 154, 1113-1118.

35. Campbell DR, Gross MD, Martini MC, Grandits GA, Slavin JL \& Potter JD (1994) Plasma carotenoids as biomarkers of vegetable and fruit intake. Cancer Epidemiol Biomarkers Prev 3, 493-500.

36. Drewnowski A, Rock CL, Henderson SA, Shore AB, Fischler C, Galan P, Preziosi P \& Hercberg S (1997) Serum beta-carotene and vitamin $\mathrm{C}$ as biomarkers of vegetable and fruit intakes in a community-based sample of French adults. Am J Clin Nutr 65, 1796-1802.

37. Jansen MC, van Kappel AL, Ocke MC, Van't Veer P, Boshuizen HC, Riboli E \& Bueno-de-Mesquita HB (2004) Plasma carotenoid levels in Dutch men and women, and the relation with vegetable and fruit consumption. Eur J Clin Nutr 58, 1386-1395.

38. Pollard J, Wild CP, White KL, Greenwood DC, Cade JE \& Kirk SF (2003) Comparison of plasma biomarkers with dietary assessment methods for fruit and vegetable intake. Eur J Clin Nutr 57, 988-998.

39. Su LJ \& Arab L (2006) Salad and raw vegetables consumption and nutritional status in the adult US population: results from the third national health and nutrition examination survey. J Am Diet Assoc 106, 1394-1404.

40. Tucker KL, Chen H, Vogel S, Wilson PW, Schaefer EJ \& Lammi-Keefe CJ (1999) Carotenoid intakes, assessed by dietary questionnaire, are associated with plasma carotenoid concentrations in an elderly population. J Nutr 129, 438-445.

41. van Kappel AL, Steghens JP, Zeleniuch-Jacquotte A, Chajes V, Toniolo P \& Riboli E (2001) Serum carotenoids as biomarkers of fruit and vegetable consumption in the New York Women's Health Study. Public Health Nutr 4, 829-835.

42. Brevik A, Andersen LF, Karlsen A, Trygg KU, Blomhoff R \& Drevon CA (2004) Six carotenoids in plasma used to assess recommended intake of fruits and vegetables in a controlled feeding study. Eur J Clin Nutr 58, 1166-1173.

43. Broekmans WM, Klopping-Ketelaars IA, Schuurman CR, Verhagen H, van den BH, Kok FJ \& van Poppel G (2000) Fruits and vegetables increase plasma carotenoids and vitamins and decrease homocysteine in humans. J Nutr 130, 1578-1583. 
44. Carroll YL, Corridan BM \& Morrissey PA (1999) Carotenoids in young and elderly healthy humans: dietary intakes, biochemical status and diet-plasma relationships. Eur J Clin Nutr 53, 644-653.

45. John JH, Ziebland S, Yudkin P, Roe LS \& Neil HA (2002) Effects of fruit and vegetable consumption on plasma antioxidant concentrations and blood pressure: a randomised controlled trial. Lancet 359, 1969-1974.

46. Le Marchand L, Hankin JH, Carter FS, Essling C, Luffey D, Franke AA, Wilkens LR, Cooney RV \& Kolonel LN (1994) A pilot study on the use of plasma carotenoids and ascorbic acid as markers of compliance to a high fruit and vegetable dietary intervention. Cancer Epidemiol Biomarkers Prev 3, 245-251.

47. Martini MC, Campbell DR, Gross MD, Grandits GA, Potter JD \& Slavin JL (1995) Plasma carotenoids as biomarkers of vegetable intake: the University of Minnesota Cancer Prevention Research Unit Feeding Studies. Cancer Epidemiol Biomarkers Prev 4, 491-496.

48. McEligot AJ, Rock CL, Flatt SW, Newman V, Faerber S \& Pierce JP (1999) Plasma carotenoids are biomarkers of longterm high vegetable intake in women with breast cancer. J Nutr 129, 2258-2263.

49. Zino S, Skeaff M, Williams S \& Mann J (1997) Randomised controlled trial of effect of fruit and vegetable consumption on plasma concentrations of lipids and antioxidants. BMJ 314, 1787-1791.

50. Al Delaimy WK, Slimani N, Ferrari P, et al. (2005) Plasma carotenoids as biomarkers of intake of fruits and vegetables: ecological-level correlations in the European Prospective Investigation into Cancer and Nutrition (EPIC). Eur J Clin Nutr 59, 1397-1408.

51. McEligot AJ, Rock CL, Shanks TG, Flatt SW, Newman V, Faerber S \& Pierce JP (1999) Comparison of serum carotenoid responses between women consuming vegetable juice and women consuming raw or cooked vegetables. Cancer Epidemiol Biomarkers Prev 8, 227-231.

52. Michaud DS, Giovannucci EL, Ascherio A, Rimm EB, Forman MR, Sampson L \& Willett WC (1998) Associations of plasma carotenoid concentrations and dietary intake of specific carotenoids in samples of two prospective cohort studies using a new carotenoid database. Cancer Epidemiol Biomarkers Prev 7, 283-290.

53. Ness AR, Khaw KT, Bingham S \& Day NE (1999) Plasma vitamin C: what does it measure? Public Health Nutr 2, $51-54$.

54. Comstock GW, Burke AE, Hoffman SC, Norkus EP, Gross M \& Helzlsouer KJ (2001) The repeatability of serum carotenoid, retinoid, and tocopherol concentrations in specimens of blood collected 15 years apart. Cancer Epidemiol Biomarkers Prev 10, 65-68.

55. Resnicow K, Odom E, Wang T, Dudley WN, Mitchell D, Vaughan R, Jackson A \& Baranowski T (2000) Validation of three food frequency questionnaires and 24 hour recalls with serum carotenoid levels in a sample of African-American adults. Am J Epidemiol 152, 1072-1080. 